\title{
Stereoselective Synthesis of Orthogonally Protected 1,2-Diaminoinositols from D-Mannose
}

\author{
Rita C. Acúrcio, ${ }^{a}$ Raquel G. Soengas, ${ }^{* a}$ Filipe A. Almeida Paz, ${ }^{\mathrm{b}}$ Artur M. S. Silva*a \\ a Department of Chemistry \& QOPNA, University of Aveiro, 3810-193 Aveiro, Portugal \\ Fax+351(234)370084; E-mail: artur.silva@ua.pt, rsoengas@ua.pt \\ b Department of Chemistry, CICECO, University of Aveiro, 3810-193 Aveiro, Portugal \\ Received: 23.05.2014; Accepted after revision: 25.06.2014
}

\begin{abstract}
We present herein a promising novel strategy for the transformation of sugar aldehydes into 1,2-diaminoinositols. This process, based on the sequential intermolecular aza-Henry reaction and intermolecular Henry reaction allowed the total synthesis of a 1,2-diaminoinositols with total stereochemical control. The new route constitutes a simpler and more efficient approach than those previously described routes to 1,2-diaminoinositols and it has the additional advantage of offering the possibility of orthogonal protection of the amino groups.
\end{abstract}

Key words: Henry reaction, aza-Henry reaction, bromonitroalkanes, 1,2-diaminoinositols, 2-nitroamines

Aminocyclitols are members of a large family of natural products with interesting biological properties ${ }^{1}$ and great importance as synthetic intermediates in natural product chemistry. ${ }^{2}$ In particular, the aminocyclitol moiety is a component of a variety of potent antibiotics, glycosidase inhibitors, and other relevant biologically active compounds. 1,2-Diaminoinositols are a group of aminocyclitols whose structure consists of a cyclohexane ring containing two vicinal amino groups and at least three additional hydroxyl groups on the ring atoms. The interest in these compounds has grown rapidly, as they are rigid scaffolds, extremely valuable for the design of chiral catalysts or ligands for asymmetric catalysis and metal complexes of value in medicinal chemistry. Thus, the 1,2-diaminoinositol framework has been incorporated into new salen asymmetric catalysts ${ }^{3}$ and also into new water-soluble antitumor platinum complexes ${ }^{4}$ and other chelating agents. ${ }^{5}$ Moreover, it was recently reported that amides derived from the simple trans-1,2-cyclohexanediamines are 'universal' gelling agents. ${ }^{6}$ Despite all this recent interest, there is only a handful of stereoselective synthetic protocols leading to orthogonally protected 1,2-diaminoinositols, and most of the described procedures afford identically $\mathrm{N}, \mathrm{N}^{\prime}$-disubstituted compounds. ${ }^{7}$

In connection with our recent research into the synthesis of carbohydrate-based stereodifferentiation agents, ${ }^{8}$ we were interested in the development of a versatile synthetic approach for the stereoselective synthesis of orthogonally protected 1,2-diaminoinositols as scaffolds for the construction of novel organocatalysts. Our route towards tar-

SYNLETT 2014, 25, 2217-2220

Advanced online publication: 06.08.2014

DOI: 10.1055/s-0034-1378545; Art ID: st-2014-d0451-1

C Georg Thieme Verlag Stuttgart · New York get inositols involves chemical manipulation of a suitably protected $\beta$-nitroamine, derived from sugar aldehydes by means of a simple and efficient protocol recently described in our group. ${ }^{9}$

Reaction of D-mannose-derived aldehyde $1,{ }^{10}$ with bromonitromethane in the presence of 4-methoxybenzenamine, titanium(IV) ethoxide, and tin(II) chloride in THF afforded a mixture of epimeric $(5 R / 5 S)$ - $\beta$-nitroamines 2 in $5: 1 \mathrm{dr}$ and $72 \%$ yield. ${ }^{\text {aa }}$ Deprotection of the anomeric position on treatment with TBAF in THF solution, followed by in situ intramolecular Henry reaction of the resulting nitrosugar $\mathbf{3}$ gave enantiopure nitroinositol $\mathbf{5}$ as the only isomer detected in the ${ }^{1} \mathrm{H}$ NMR spectrum of the crude reaction mixture (Scheme 1). ${ }^{11}$

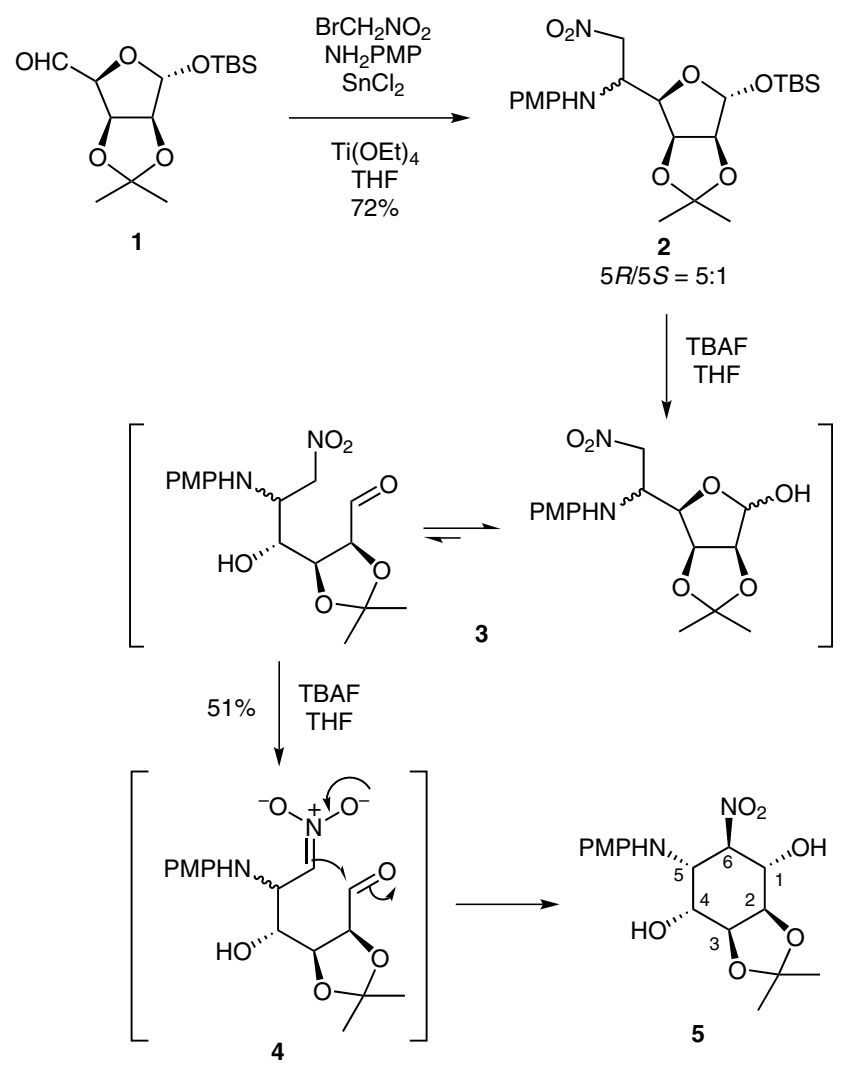

Scheme 1 Synthesis of nitroinositol 5 from sugar aldehyde 1

The stereochemistry of compound $\mathbf{5}$ was firmly established using single-crystal X-ray diffraction, ${ }^{12}$ with the Flack parameter of the $P 1$ determination converging to 

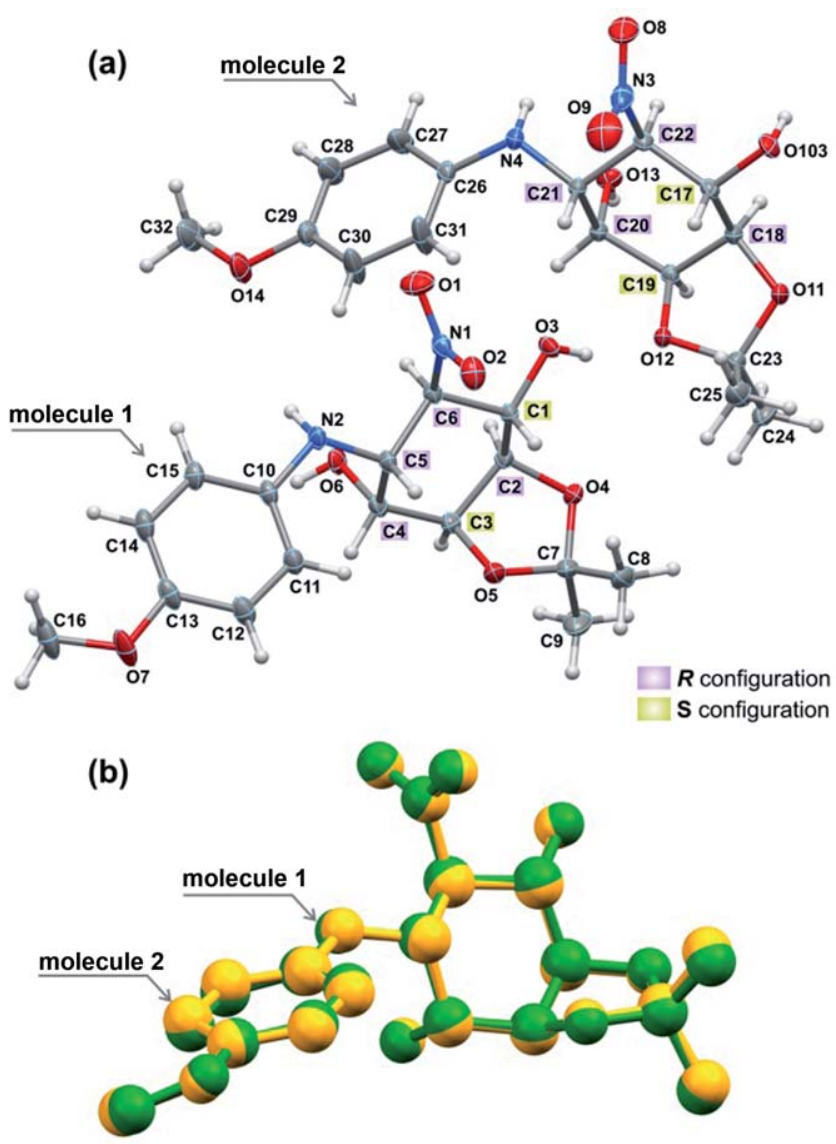

Figure 1 (a) Molecular units composing the asymmetric unit of the crystal structure of the nitroinositol $\mathbf{5}$, emphasizing the configuration for each chiral carbon atom. Nonhydrogen atoms are represented as thermal ellipsoids drawn at the $60 \%$ probability level and hydrogen atoms as small spheres with arbitrary radii. Note: The atomic labelling herein only concerns the crystallographic description of the molecules and it is not related to that described in the main text. (b) Overlay of the two crystallographically independent molecular units showing that the differences between the molecules are essentially due to rotations of the functional groups: maximum distance of ca. $0.21 \AA$ with a RMSD of $0.11 \AA$.

$0.0(3) .{ }^{13}$ At $100 \mathrm{~K}$ the nitroinositol 5 crystallizes in the noncentrosymmetric and chiral $P 1$ space group, with the asymmetric unit being composed by two independent molecular units as depicted in Figure 1 (a). Both molecules exhibit, nevertheless, the same stereochemistry for the sixmembered ring: $S, R, S, R, R, R$ for C-1,C-2,C-3,C-4,C-5,C-6, and C-17,C-18,C-19,C-20,C-21,C-22 [see Figure 1 (a)]. It is worth noting that this ring exhibits the favored chair conformation, with an equatorial disposition of the C-3,C4 and C-19,C-20 hydrogen atoms, and an axial disposition for the remaining ones. We further note that this conformation is also the one favored in solution, a fact readily established from examination of the ${ }^{1} \mathrm{H}$ NMR spectrum of 5 , which includes a double doublet at $\delta=4.73 \mathrm{ppm}$ due to the highly deshielded $\mathrm{H}-1$. The coupling constants $\left(J_{1,2}=\right.$ $10.5 \mathrm{~Hz}$ and $J_{1,6}=10.5 \mathrm{~Hz}$ ) indicate an axial disposition for proton $\mathrm{H}-1$ as well as for adjacent protons $\mathrm{H}-6$ and $\mathrm{H}-$ 2. On the other hand, the coupling constants for the dou- blet at $\delta=4.11 \mathrm{ppm}\left(J_{1,6}=10.5 \mathrm{~Hz}\right.$ and $\left.J_{5,6}=3.0 \mathrm{~Hz}\right)$, corresponding to proton $\mathrm{H}-6$, allowed us to confirm the axial disposition of this proton and the equatorial disposition of the proton $\mathrm{H}-5$.

In the solid state, each individual molecular unit of nitroinositol $\mathbf{5}$ is engaged in a range of supramolecular contacts, mostly arising from strong and highly directional hydrogen-bonding interactions [see the Supporting Information (SI)]. Considering solely the $\mathrm{N}-\mathrm{H} \cdots \mathrm{O}, \mathrm{O}-\mathrm{H} \cdots \mathrm{O}$ and $\mathrm{O}-$ $\mathrm{H} \cdots \mathrm{N}$ interactions (see Table S1), the two crystallographically independent molecular units describe a two-dimensional supramolecular layer placed in the $b c$ plane of the unit cell (Figure S1a). Individual layers close pack in the [001] direction to form the crystal structure of 5 (Figure $\mathrm{S} 1 b$ ). Weaker supramolecular interactions are also present in the crystal structure, namely various weak $\mathrm{C}-\mathrm{H} \cdots \mathrm{O}$ hydrogen bonds (Table S1 and Figure $\mathrm{S} 2$ ) and $\mathrm{C}-\mathrm{H} \cdots \pi$ contacts (Table S1 and Figure S3). It is noteworthy that each individual molecular unit is engaged in a different set of these supramolecular interactions as depicted in Figures S2 and S3. This structural feature helps to understand the reason for the presence of these two conformational isomers composing the asymmetric unit of $\mathbf{5}$.

The fact that reaction of the isomeric mixture 2 afforded enantiopure nitroinositol $\mathbf{5}$ as single isomer may be attributed to the reversibility of Henry and aza-Henry reactions, ${ }^{14}$ allowing isomeric equilibration through openchain derivatives. ${ }^{15}$ Consequently; whereas carbanion $4 a$, the reaction intermediate derived from nitrosugar $5 R$, proceeds easily to nitroinositol $\mathbf{5}$, its epimer $\mathbf{4 b}$ (the intermediate derived from nitrosugar $5 S$ ) gives initially nitroinositol $\mathbf{6}$, which isomerizes to the more thermodynamically stable nitroinositol 5 through compound 7 via a retro-aza-Henry-aza-Henry sequence (Scheme 2).

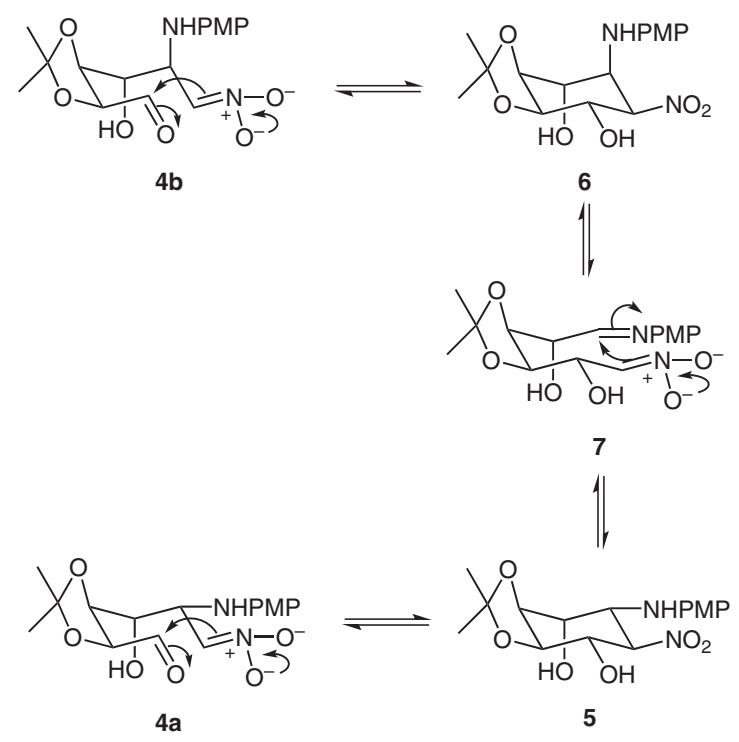

Scheme 2 Mechanistic proposal for the formation of nitroinositol 5

The free hydroxyl groups of nitroinositol $\mathbf{5}$ were protected by treatment with tris(triethyl)silyl chloride and imidazole 
in DMF, before reduction of the nitro group. Thus, reaction of the resulting protected nitroinositol $\mathbf{8}$ with zinc powder in the presence of dilute hydrochloric acid as protic medium afforded 1,2-diaminoinositol 9 in good yield, preserving the stereochemistry of all stereogenic centres. ${ }^{16}$ Finally, the free amino group of the 1,2-diaminoinositol 9 was protected with a $\mathrm{Cbz}$ group under SchottenBaumann ${ }^{17}$ conditions to afford the desired 1,2-diaminoinositol 10 (Scheme 3). ${ }^{18}$<smiles>CC(C)NN[C@@H]1[C@H]([N+](=O)[O-])[C@H]2OC(C)(C)O[C@H]2[C@@H](O)[C@@H]1O</smiles>
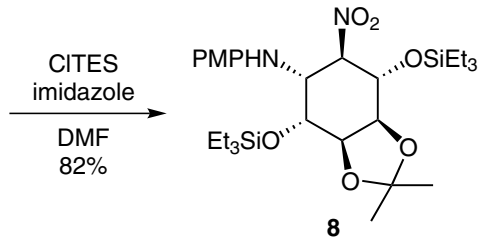

$$
71 \% \downarrow \substack{\mathrm{Zn}, \mathrm{HCl}(1 \mathrm{M}) \\ i-\mathrm{PrOH}}
$$<smiles>CCO[C@H]1[C@@H](NC(C)=O)[C@H](NC(C)=O)[C@@H](OCC)[C@@H]2OC(C)(C)O[C@H]12</smiles>
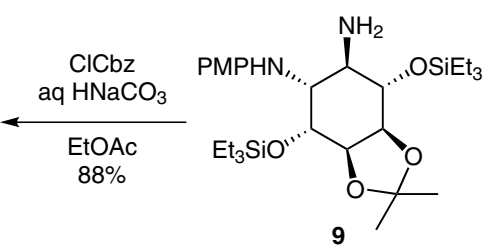

Scheme 3 Synthesis of 1,2-diaminoinositol 10

In summary, we describe herein the transformation of a sugar (D-mannose) into an orthogonally protected 1,2-diamino inositol. Our strategy for the construction of the cyclohexane ring of target inositol from a sugar aldehyde involves an intermolecular aza-Henry reaction followed by an intramolecular Henry reaction. A salient feature of this sequence is the total stereoselectivity of the ring formation, due to equilibration to the most thermodynamically stable nitroinositol. This new chemistry could be used for the transformation of sugar-derived dialdehydes into 2-nitroaminoinositols, that could in turn be converted into orthogonally protected 1,2-diaminoinositols, a class of compounds of great synthetic interest that have not been studied to any great extent. Future efforts will focus on the application of the new method to the synthesis of diverse 1,2-diaminoinositols with a view to their use for the preparation of novel organocatalysts.

\section{Acknowledgment}

Thanks are due to the University of Aveiro, Fundação para a Ciência e a Tecnologia (FCT), European Union, QREN, FEDER, and COMPETE for funding the Organic Chemistry Research Unit (project PEst-C/QUI/UI0062/2013), the Associated Laboratory CICECO (Pest-C/CTM/LA0011/2013) and the Portuguese National NMR Network (RNRMN). R.S. thanks the FCT for an 'Investigador Auxiliar' position.

Supporting Information for this article is available online at http://www.thieme-connect.com/products/ejournals/journal/ $10.1055 / \mathrm{s}-00000083$

\section{References and Notes}

(1) (a) Ogawa, S. In Carbohydrates in Drug Design; Witczak, Z.; Nieforth, K., Eds.; Dekker: New York, 1997, 433-469. (b) Diaz, L. Curr. Med. Chem. 2010, 17, 2393.

(2) (a) Schilling, S.; Rinner, U.; Chan, C.; Ghiviriga, I.; Hudlicky, T. Can. J. Chem. 2001, 79, 1659. (b) Frontier, A. J.; Raghavan, S.; Danishefsky, S. J. J. Am. Chem. Soc. 2000, 122, 6151. (c) Suzuki, T.; Tanaka, S.; Yamada, I.; Koashi, Y.; Yamada, K.; Chida, N. Org. Lett. 2000, 2, 1137.

(3) (a) Paul, B. J.; Willis, J.; Martinot, T. A.; Ghiviriga, I.; Abboud, K. A.; Hudlicky, T. J. Am. Chem. Soc. 2002, 124, 10416. (b) Azev, V. N.; D’Alarcao, M. J. Org. Chem. 2004, 69,4839 .

(4) (a) Suami, T.; Shiio, T.; Kazuo, O.; Kunisuke, I. JP 86161529, 1988. (b) Suami, T.; Takeshi, S. JP 85127551, 1986.

(5) Ouadi, A.; Loussouarn, A.; Morandeau, L.; Remaud, P.; Faivre-Chauvet, A.; Webb, J.; Gestin, J.-F. Eur. J. Med. Chem. 2004, 39, 467.

(6) Menger, F. M. Proc. Natl. Acad. Sci. U.S.A. 2002, 99, 4818.

(7) For the aziridine ring opening, see: (a) Serrano, P.; Llebaria, A.; Delgado, A. J. Org. Chem. 2005, 70, 7829. (b) Paul, B. J.; Martinot, T. A.; Willis, J.; Hudlicky, T. Synthesis 2001, 952. (c) Paulsen, H.; Mielke, B. Liebigs Ann. Chem. 1990 169. (d) Kresze, G.; Melzer, H. Liebigs Ann. Chem. 1981, 1874. For the reaction of a trans-1,2-dimesylate with sodium azide, see: (e) De Almeida, M. V.; Figueiredo, R. M.; Dos Santos, H. F.; Da Silva, A. D.; De Almeida, W. B. Tetrahedron Lett. 2001, 42, 2767.

(8) (a) Soengas, R. G.; Silva, A. M. S. Tetrahedron 2013, 69, 3425. (b) Soengas, R. G.; Silva, A. M. S. Tetrahedron Lett. 2013, 54, 2156.

(9) (a) Soengas, R. G.; Silva, A. M. S. Synlett 2013, 24, 1949. (b) Soengas, R. G.; Silva, S.; Estévez, A. M.; Estévez, J. C.; Estévez, R. J.; Rodríguez-Solla, H. Eur. J. Org. Chem. 2012, 4339. (c) Rodríguez-Solla, H.; Concellón, C.; Alvaredo, N.; Soengas, R. G. Tetrahedron 2012, 68, 1736.

(10) Brewster, K.; Harrison, J. M.; Inch, T. D.; Williams, N. J. Chem. Soc., Perkin Trans. 1 1987, 21.

(11) 1-D-[1,4,5/2,3,6]-2,3-O-Isopropylidene-5-(4-methoxyphenylamino)-6-nitrocyclohexane-1,2,3,4-tetraol (5) $\mathrm{Mp} 155-158^{\circ} \mathrm{C}\left(\mathrm{Et}_{2} \mathrm{O}\right.$-hexane). $[\alpha]_{\mathrm{D}}{ }^{22}+5.2$ (c 0.9 in $\left.\mathrm{CDCl}_{3}\right) .{ }^{1} \mathrm{H} \mathrm{NMR}\left(300 \mathrm{MHz}, \mathrm{CDCl}_{3}\right): \delta=6.76($ app q, $J=$ $8.5 \mathrm{~Hz}, 2 \mathrm{H}$ ), 6.65 (app q, $J=8.5 \mathrm{~Hz}, 2 \mathrm{H}$ ), 4.73 (dd, $J=10.5$ $\mathrm{Hz}, 1 \mathrm{H}), 4.32-4.21(\mathrm{~m}, 4 \mathrm{H}), 4.11(\mathrm{dd}, J=10.5,3.0 \mathrm{~Hz}, 1$ $\mathrm{H}), 3.72(\mathrm{~s}, 3 \mathrm{H}), 1.58(\mathrm{~s}, 3 \mathrm{H}), 1.36(\mathrm{~s}, 3 \mathrm{H}) .{ }^{13} \mathrm{C}$ NMR $(100$ $\left.\mathrm{MHz}, \mathrm{CDCl}_{3}\right): \delta=153.6(\mathrm{C}), 139.3(\mathrm{C}), 116.6(2 \times \mathrm{CH})$, $114.9(2 \times \mathrm{CH}), 110.4(\mathrm{C}), 88.2(\mathrm{CH}), 78.7(\mathrm{CH}), 73.7(\mathrm{CH})$, $66.9(\mathrm{CH}), 55.7\left(\mathrm{CH}_{3}\right), 32.9(\mathrm{CH}), 28.0\left(\mathrm{CH}_{3}\right), 25.9\left(\mathrm{CH}_{3}\right)$. MS $\left(\mathrm{ESI}^{+}\right): m / z(\%)=355(100)[\mathrm{M}+\mathrm{H}]^{+}$. HRMS $\left(\mathrm{ESI}^{+}\right)$: $m / z$ calcd for $\mathrm{C}_{16} \mathrm{H}_{23} \mathrm{~N}_{2} \mathrm{O}_{7}[\mathrm{M}+\mathrm{H}]^{+}: 355.1496$; found: 355.1500 .

(12) Crystal Data for 5

$\mathrm{C}_{16} \mathrm{H}_{22} \mathrm{~N}_{2} \mathrm{O}_{7}, M=354.36$, triclinic, space group $P 1 Z=2$, $a$ $=9.7564(18) \AA, b=9.9572(18) \AA, c=10.1902(17) \AA, \alpha=$ $109.194(6)^{\circ}, \beta=111.437(6)^{\circ}, \gamma=90.714(7)^{\circ}, V=860.3(3)$ $\AA^{3}, \mu(\mathrm{Mo}-\mathrm{K} \alpha)=0.108 \mathrm{~mm}^{-1}, D_{\mathrm{c}}=1.368 \mathrm{~g} \mathrm{~cm}^{-3}$, yellow block with crystal size of $0.47 \times 0.34 \times 0.33 \mathrm{~mm}^{3}$. Of a total of 69400 reflections collected, 10280 were independent $\left(R_{\text {int }}\right.$ $=0.0254)$. Final $R 1=0.0301[I>2 \sigma(I)]$ and $w R 2=0.0772$ (all data). Data completeness to theta $=30.50^{\circ}, 100.0 \%$. CCDC 990920.

(13) (a) Flack, H. D. Acta Crystallogr., Sect. A: Found. Crystallogr. 1983, 39, 876. (b) Flack, H. D.; Bernardinelli, G. Acta Crystallogr., Sect. A: Found. Crystallogr. 1999, 55, 908. (c) Flack, H. D.; Bernardinelli, G. J. Appl. Crystallogr. 2000, 33, 1143 . 
(14) Soengas, R. G.; Estévez, J. C.; Estevez, A. M.; Fernández, F.; Estévez, R. J. In Carbohydr. Chem.; Vol. 35; Rauter, A. P.; Linhorst, T., Eds.; RSC: Cambridge, 2009, 173-198.

(15) (a) Soengas, R. G.; Estévez, J. C.; Estévez, R. J. Tetrahedron 2003, 59, 6285. (b) Soengas, R. G.; Estévez, J. C.; Estévez, R. J.; Maestro, M. A. Tetrahedron: Asymmetry 2003, 14, 1653.

(16) Bernardi, L.; Bonini, B. F.; Capitó, E.; Dessole, G.; ComesFranchini, M.; Fochi, M.; Ricci, A. J. Org. Chem. 2004, 69, 8168.

(17) (a) Schotten, C. Ber. Dtsch. Chem. Ges. 1884, 17, 2544. (b) Baumann, E. Ber. Dtsch. Chem. Ges. 1886, 19, 3218.

(18) 1-D-[1,4,5/2,3,6]-6-Benzyloxycarbonylamino-2,3-Oisopropylidene-5-(4-methoxyphenylamino)-1,4-di- $O$ triethylsilylcyclohexane-1,2,3,4-tetraol (10) $[\alpha]_{\mathrm{D}}{ }^{22}+0.6\left(c 0.2\right.$ in $\left.\mathrm{CDCl}_{3}\right) .{ }^{1} \mathrm{H}$ NMR $\left(300 \mathrm{MHz}, \mathrm{CDCl}_{3}\right): \delta$ $=7.31-7.25(\mathrm{~m}, 5 \mathrm{H}), 6.73($ app q, $J=8.5 \mathrm{~Hz}, 2 \mathrm{H}), 6.50($ app q, $J=8.5 \mathrm{~Hz}, 2 \mathrm{H}), 5.02(\mathrm{~s}, 2 \mathrm{H}), 4.49(\mathrm{~d}, J=9.0 \mathrm{~Hz}, 1 \mathrm{H})$, 4.33 (br s, $1 \mathrm{H}), 4.15-4.06(\mathrm{~m}, 2 \mathrm{H}), 3.96-3.86(\mathrm{~m}, 2 \mathrm{H})$, 4.15-4.06 (m, $2 \mathrm{H}), 3.72$ (s, $3 \mathrm{H}), 3.69-3.55(\mathrm{~m}, 2 \mathrm{H}), 1.52$ $(\mathrm{s}, 3 \mathrm{H}), 1.37(\mathrm{~s}, 3 \mathrm{H}), 0.95-0.90(\mathrm{~m}, 18 \mathrm{H}), 0.66-0.55(\mathrm{~m}, 12$ H). ${ }^{13} \mathrm{C} \mathrm{NMR}\left(100 \mathrm{MHz}, \mathrm{CDCl}_{3}\right): \delta=157.1(\mathrm{C}), 151.8(\mathrm{C})$, 141.77(C), $136.5(\mathrm{C}), 128.4(2 \times \mathrm{CH}), 128.0(2 \times \mathrm{CH}), 115.0$ $(2 \times \mathrm{CH}), 114.0(2 \times \mathrm{CH}), 109.2(\mathrm{C}), 80.9(\mathrm{CH}), 77.7(\mathrm{CH})$, $68.8(\mathrm{CH}), 66.2\left(\mathrm{CH}_{2}\right), 55.9(\mathrm{CH}), 55.8\left(\mathrm{CH}_{3}\right), 53.8(\mathrm{CH})$, $28.4\left(\mathrm{CH}_{3}\right), 26.3\left(\mathrm{CH}_{3}\right), 6.8\left(6 \times \mathrm{CH}_{3}\right), 5.0\left(3 \times \mathrm{CH}_{2}\right), 4.8(3$ $\left.\times \mathrm{CH}_{2}\right) . \mathrm{MS}\left(\mathrm{ESI}^{+}\right): m / z(\%)=687(100)[\mathrm{M}+\mathrm{H}]^{+}$. HRMS $\left(\mathrm{ESI}^{+}\right): \mathrm{m} / z$ calcd for $\mathrm{C}_{36} \mathrm{H}_{59} \mathrm{~N}_{2} \mathrm{O}_{7} \mathrm{Si}_{2}[\mathrm{M}+\mathrm{H}]^{+}: 687.3843$; found: 687.3855. 
Copyright of Synlett is the property of Georg Thieme Verlag Stuttgart and its content may not be copied or emailed to multiple sites or posted to a listserv without the copyright holder's express written permission. However, users may print, download, or email articles for individual use. 